\title{
PENGARUH PROFITABILITAS, UKURAN PERUSAHAAN, STRUKTUR AKTIVA DAN PERTUMBUHAN PENJUALAN TERHADAP STRUKTUR MODAL PADA PERUSAHAAN MANUFAKTUR YANG TERDAFTAR DI BURSA EFEK INDONESIA PERIODE 2012-2016
}

\author{
Sri Wiranti Setiyanti, Dwi Prawani SR, Rosvita Kuriani Uba Pari \\ Program Studi Manajemen STIE SEMARANG
}

\begin{abstract}
Capital structure is the mix (proportion) of a company's long-term permanent funding indicated by debt, preferred stock equity and ordinary shares. The purpose of this study was to determine the effect of profitability, company size, asset structure and sales growth on the capital structure of manufacturing companies listed on the Indonesia Stock Exchange in 2012 - 2016. The population in this study were all manufacturing companies listed on the Indonesia Stock Exchange (IDX) in 2012-2016 totaling 149 companies. The sampling technique used a purposive sampling method so that the number of samples of 25 companies was obtained. The method of collecting data in this study is the documentation method. The data analysis method used is multiple linear regression. The results showed that the variable profitability and firm size did not have a significant effect on capital structure. Variable asset structure and sales growth had a significant effect on capital structure. Suggestions that can be given is that for future research, it is expected to increase the variables that affect capital structure such as liquidity ratios, business risks, liabilities and so on. For investors, it is necessary to look at the company's capital structure as a consideration for investing in order to get the return value as desired and for the manufacturing industry to be able to consider asset structure factors and maintain sales growth to remain stable in managing the company.
\end{abstract}

Keywords: Profitability, Company Size, Structure of Assets, Growth, Sales and Capital Structure

\begin{abstract}
ABSTRAK
Struktur modal adalah bauran (proporsi) pendanaan permanen jangka panjang perusahaan yang ditunjukkan oleh hutang, ekuitas saham preferen dan saham biasa. Tujuan penelitian ini adalah untuk mengetahui pengaruh antara profitabilitas, ukuran perusahaan, struktur aktiva dan pertumbuhan penjualan terhadap struktur modal pada perusahaan manufaktur yang terdaftar di Bursa Efek Indonesia tahun 2012 - 2016.Populasi dalam penelitian ini adalah seluruh perusahaan manufaktur yang terdaftar di Bursa Efek Indonesia (BEI) tahun 20122016 berjumlah 149 perusahaan. Teknik pengambilan sampel menggunakan metode purposive sampling sehingga didapatkan jumlah sampel 25 perusahaan. Metode pengumpulan data penelitian ini adalah metode dokumentasi. Metode analisis data yang digunakan adalah regresi linier berganda.Hasil penelitian menunjukkan bahwa variabel profitabilitas dan ukuran perusahaantidak berpengaruh signifikan terhadap struktur modal.Variabel struktur aktiva dan pertumbuhan penjualan berpengaruh signifikan terhadap struktur modal.Saran yang dapat diberikan adalah bagi penelitian yang akan datang diharapkan dapat memperbanyak variabel yang mempengaruhi struktur modal seperti rasio likuiditas, resiko bisnis, liabilitas dan lain sebagainya.Bagi investorperlu melihat struktur modal perusahaan sebagai bahan pertimbangan untuk berinvestasi guna mendapatkan nilai pengembalian sesuai yang diinginkan dan untuk industri manufaktur agar dapat mempertimbangkan faktor struktur aktiva dan menjaga pertumbuhan penjualannya agar tetap stabil dalam mengelola perusahaan.
\end{abstract}

Kata kunci: Profitabilitas, Ukuran Perusahaan, Sruktur Aktiva, Pertumbuhan Penjualan dan Struktur Modal 


\section{PENDAHULUAN}

Latar Belakang Masalah

Modal merupakan salah satu unsur penting dalam meningkatkan pelaksanaan kegiatan perusahaan. Pemenuhan kebutuhan dana atau modal dapat diperoleh dari dalam perusahaan (sumber internal, berupa modal sendiri dan laba ditahan) dan dari luar perusahaan (sumber eksternal, berupa modal asing atau hutang). Struktur modal merupakan pembelanjaan permanen yang mencerminkan perbandingan antara hutang jangka panjang dengan modal sendiri.Struktur modal dapat diukur dengan rasio perbandingan antara total hutang terhadap modal sendiri melalui Debt to Equity Ratio(DER) (Husnan, 2011). Semakin besar DER maka semakin besar pula risiko yang harus dihadapi perusahaan, karena pemakaian hutang sebagai sumber pendanaan jauh lebih besar dari pada modal sendiri. Perusahaan yang baik adalah perusahaan yang dapat menentukan pendanaan yang murah dengan bunga rendah dan jangka waktu fleksibel, sehingga utang menjadi menguntungkan bagi perusahaan

Faktor-faktor yang mempengaruhi struktur modal (Weston dan Brigham, 1991) adalah struktur aktiva, stabilitas penjualan, elastisitas operasi, tingkat pertumbuhan, profitabilitas, pajak, pengendalian, sikap manajemen, sikap kreditur, kondisi pasar dan kondisi internal perusahaan. Pada penelitian iniakan mencoba menganalisis faktor-faktor yang mempengaruhi struktur modalperusahaan manufaktur yang terdaftar di Bursa Efek Indonesia periode 2012 2016, adapun faktor-faktor yang akan diteliti adalahprofitabilitas, ukuran perusahaan, struktur aktiva dan pertumbuhan penjualan.

Perusahaan dengan tingkat profitabilitas yang tinggi akan menggunakan hutang yang relatif kecil, karena perusahaan mampu menyediakan dana yang cukup melalui laba ditahan ataudengan dana yang dihasilkan secara internal (Sartono, 1996). Perusahaan yang berskala besar akan lebih mudah dalam mendapatkan investor yang hendak menanamkan modal dan dalam hal perolehan kredit dibanding perusahaan kecil, maka semakin besar ukuran suatu perusahaan semakin besar pula kesempatan perusahaan tersebut memperoleh pendanaan eksternal.Aktiva yang dimiliki oleh perusahaan dapat digunakan sebagai jaminan untuk memperoleh pinjaman. Perusahaan yang sebagian besar aktivanya berupa aktiva tetap, akan menggunakan hutang jangka panjang yang lebih besar (Weston dan Brigham, 1991). Perkembangan peningkatan penjualan perusahaan akan menghasilkan peningkatan keuntungannya juga sehingga pilihan perusahaan cenderung menggunakan dana internal dalam pembiayaan aktivitas operasionalnya (Brealey, dkk, 2008)

Penelitian yang dilakukan oleh Hadianto (2010), menunjukkan hasil bahwa struktur aktiva berpengaruh negatif dan signifikan terhadap struktur modal.Sedangkan penelitian yang 
dilakukan oleh Liwang (2011) menunjukkan bahwastruktur aktiva berpengaruh positif dan signifikan terhadap struktur modal.

Hal ini didukung oleh penelitian Sulistyowati (2009) dan Muhardi (2011) dengan menyimpulkan pertumbuhan penjualan (sales growth) berpengaruh pada struktur modal.Sedangkan penelitian Wijaya dan Karya Utama (2014), Erdiana (2011), Indrajaya (2011) dan Priambodo, dkk (2014) hasilnya menunjukkan bahwa pertumbuhan penjualan berpengaruh negatif pada struktur modal.

\section{MASALAH PENELITIAN}

Berdasarkan latar belakang yang mendasari permasalahan yang ada, maka dapatdirumuskan masalah penelitian yaitu "Apakah profitabilitas, ukuran perusahaan, struktur aktiva dan pertumbuhan penjualan berpengaruh signifikan terhadap struktur modal perusahaan manufaktur yang terdaftar di Bursa Efek Indonesia periode 2012 - 2016”

\section{KAJIAN TEORITIS}

Pengertian Struktur Modal

Struktur modal merupakan bagian dari struktur keuangan.Struktur modal adalah perimbangan atau perbandingan antarajumlah hutang jangka panjang dengan modal sendiri (Riyanto, 2001).Sedangkan menurut Van Horne dan Wachowicz(2007) struktur modal adalah bauran (proporsi) pendanaanpermanen jangka panjang perusahaan yang ditunjukkan oleh hutang, ekuitas saham preferen dan saham biasa.Adanya struktur modal yang ditargetkan dapat membantuperusahaan untuk selalu konsisten di dalam menentukan struktur modal.

Struktur atau komposisi modal harus diatur sedemikianrupa sehingga terjamin stabilitas finansial perusahaan, memangtidak ada ukuran yang pasti mengenai jumlah dan komposisi modaldari tiap-tiap perusahaan.Namun pada dasarnya pengaturanterhadap struktur modal dalam perusahaan harus berorientasi padatercapainya stabilitas financialdan terjaminnya kelangsunganhidup perusahaan.

\section{Teori Struktur Modal}

a. Teori Modigliani dan Miller (MM)

Teori mengenai struktur modal modern ini pertama kali dikemukakan oleh Franco Modigliani dan Merton H.Miller pada tahun 1958 yang dikenal dengan teori MM. Modigliani dan Miller mengatakan bahwa penggunaan hutang akan lebih menguntungkan apabila dibandingkan dengan penggunaan modal sendiri, terutama dengan meminjam ke 
perbankan. Teori ini mengeluarkan asumsi pertama yang menyatakan bahwa jika dalam keadaan perfect capital market dan tidak ada pajak, struktur modal yang digunakan perusahaan tidak mempengaruhi nilai perusahaan.Menurut Modigliani dan Miller(1958), rasio hutang tidak relevan dan tidak ada struktur modal yang optimal dan nilai perusahaan bergantung pada arus kas yang dihasilkan dan bukan pada rasio hutang dan ekuitas.

Namun asumsi pertama ini dianggap tidak relevan karena jika dibebankan pajak, maka perusahaan akan menggunakan utang lebih banyak karena pembayaran bunga hutang akan mengurangi beban pajak. Sehingga Modigliani dan Miller memperbaiki asumsi pertamanya dengan menerbitkan makalah yang melemahkan asumsi sebelumnya mengenai tidak adanya pajak perseroan.Dengan adanya beban pajak yang harus di tanggung oleh perusahaan dari pembayaran bunga sebagai beban, tetapi sebagai pengurang untuk pembayaran deviden kepada pemegang saham.Sehingga teori ini mendorong perusahaan untuk menggunakan hutang terlebih dahulu daripada modal sendiri dalam struktur modalnya disebabkan dengan adanya beban bunga akan mengurangi pembayaran pajak perseroan kepada pemerintah.

b. Teori Pertukaran (Trade-Off Theory)

Teori pertukaran (trade Off Theory) menyatakan bahwa perusahaan menukar manfaat pajak dari pendanaan utang dengan masalah yang ditimbulkan oleh potensi kebangkrutan.Joni dan Lina (2010) menyatakan bahwa rasio hutang yang optimal ditentukan berdasarkan pada perimbangan antara manfaat dan biaya yang timbul akibat penggunaan hutang. Secara prinsip, tambahan hutang masih dapat dilakukan perusahaan selama manfaat yang diberikan masih jauh lebih besar dan adanya asset tetap sebagai jaminan, tetapi jika biaya hutang sudah terlalu tinggi, perusahaan seharusnya tidak menambah hutang lagi untuk menghindari resiko yang tidak diinginkan yang dapat mempengaruhi nilai perusahaan. Disisi lain, apabila perusahaan menggunakan sumber pendanaan hanya dari hutang maka perusahaan tidak akan mencapai nilai optimal.

Menurut Brigham dan Houston (2009), trade-off theory memasukkan beberapa faktor dalam menentukan struktur modal yang optimal antara lain pajak, biaya keagenan (agency cost) dan biaya kesulitan keuangan (financial distress) tetapi tetap mempertahankan asumsi efisiensi pasar dan symmetric information sebagai imbangandan manfat penggunaan hutang. Tingkat hutang yang optimal tercapai ketika penghematan pajak (tax shields) mencapai jumlah yang maksimal terhadap biaya kesulitan keuangan (cost of financial distress). 


\section{c. Teori Pecking Order}

Teori pecking order theory dikemukakan oleh Myers dan Maljuf pada tahun 1984. Teori ini secara ringkas menjelaskan bahwa keputusan pendanaan perusahaan cenderung menggunakan sumber dana internal (laba ditahan dan depresiasi) terlebih dahulu daripada sumber eksternal (hutang dan saham) untuk struktur modalnya. Pendanaan bersumber dari utang digunakan apabila dana internal tidak mencukupi dan memadai.

Pecking order theory (Myers \& Majluf, 1984), pilihan pendanaan perusahaan didorong oleh biaya pemilihan kerugian (cost of adverse selection) yang timbul sebagai hasil dari informasi asimetris antara better informed managersdan less informed investor. Biaya informasi asimetris ini timbul ketika perusahaan menerbitkan surat berharga yang sangat tinggi terutama untuk saham. Akibatnya, perusahaan menerbitkan ekuitas sebagai pilihan terakhir.

\section{Komponen Struktur Modal}

a. Modal Sendiri

Modal sendiri pada dasarnya adalah modal yang berasaldari pemiliknya dan tertanam di dalam perusahaan untuk waktuyang tidak tentu lamanya (Riyanto, 2001). Modal sendiri jugadapat didefinisikan sebagai dana yang dipinjam dalam jangkawaktu tidak terbatas dari para pemegang saham. Secara umumdikatakan pinjaman baru dikembalikan kepada para pemegangsaham bilamana perusahaan tersebut dipailitkan.Sumber modalsendiri berasal dari dalam perusahaan maupun luar perusahaan.Sumber dari dalam (internal financing) berasal dari hasil operasiperusahaan yang berbentuk laba ditahan dan penyusutan.Sedangkan dari luar (external financing) bisa dalam bentuk sahambiasa atau saham preferen ( Husnan, 2011).

Komponen modal sendiri ini merupakan modal perusahanyang dipertaruhkan untuk segala risiko, baik risiko usaha maupunrisiko - risiko kerugian lainnya.Modal sendiri ini tidakmemperlukan jaminan atau keharusan untuk pembayaran kembalidalam setiap keadaan maupun tidak adanya kepastian tentangjangka waktu pembayaran kembali modal sendiri.Oleh karena itu,tiap-tiap perusahaan harus mempunyai jumlah minimum modalyang diperlukan untuk menjamin kelangsungan hidup perusahaan.Modal sendiri yang bersifat permanen akan tetap tertanam dalam perusahaan dan dapat diperhitungkan pada setiap saat untukmemelihara kelangsungan hidup dan melindungi perusahan dari risiko kebangkrutan. 
b. Utang Jangka Panjang

Modal asing atau jangka panjang adalah utang yang jangkawaktunya adalah panjang, umumnya lebih dari sepuluh tahun(Riyanto, 2001).Utang jangka panjang adalah kewajiban keuanganyang dalam melakukan pembayaran lebih dari satu tahun.Utangjangka panjang ini pada umumnya digunakan untuk membelanjaperluasan (ekspansi) atau modernisasi dari perusahaan, karenakebutuhan modal untuk keperluan tersebut meliputi jumlah besar(Riyanto, 2001).

\section{Faktor-Faktor yang Mempengaruhi Struktur Modal}

a. Profitabilitas

Profitabilitas adalah kemampuan perusahaan dalam memperoleh laba.Brigham dan Houston (2008) mengatakan bahwa perusahaan dengan tingkat pengembalian tinggi atas investasi menggunakan hutang yang relatif kecil. Tingkat pengembalian yang tinggi memungkinkan untuk membiayai sebagian besar kebutuhan pendanaan dengan dana yang dihasilkan secara internal. Profitabilitas juga mempunyai arti penting dalam usaha mempertahankan kelangsungan hidupnya dalam jangka panjang, karena profitabilitas menunjukkan apakah perusahaan mempunyai prospek yang baik di masa yang akandatang. Pengukuran profitabilitas yang lazim digunakan untuk menganalisis rasio profitabilitas adalah sebagai berikut :

\section{Net profit margin(NPM)}

Yaitu membandingkan antara laba bersih dengan penjualan yang dihasilkan oleh perusahaan. Pengukuran ini akan menunjukkan seberapa besar laba bersih yang dapat dihasilkan oleh tingkat penjualan dari perusahaan tersebut.

2. Return on asset(ROA)

Yaitu membandingkan antara laba bersih dengan total aset dari perusahaan. Pengukuran ini akan menunjukkan seberapa besar laba bersih yang dapat dihasilkan oleh total aset dari perusahaan tersebut.

\section{Return on equity (ROE)}

Yaitu membandingkan antara laba bersih dengan modal sendiri dari perusahaan. Pengukuran ini akan menunjukkan seberapa besar laba bersih yang dapat dihasilkan akan modal sendiri dari perusahaan tersebut. Suatu perusahaan yang mempunyai tingkat profitabilitas tinggi akan cenderung membiayai perusahaan dengan modal sendiri yaitu dengan laba ditahan dan juga saham. Hal ini disebabkan karena dengan tingkat profitabilitas yang tinggi, maka nilai saham akanmeningkat dan hal ini akan 
dimanfaatkan oleh perusahaan untuk mendapatkan dana tambahan dengan menjual saham-saham yang nilainya telah meningkat tersebut.

\section{b. Ukuran Perusahaan}

Ukuran perusahaan dapat diartikan sebagai besar kecilnya perusahaan dilihat dari besarnya nilai equity, nilai perusahaan, ataupun hasil nilai total aktiva dari suatu perusahaan. Semakin besar ukuran suatu perusahaan, maka kecenderungan menggunakan sumber dana eksternal juga semakin besar. Hal ini disebabkankarena perusahaan besarmembutuhkan dana yang besar pula untuk menunjangoperasionalnya, dan salah satualternatif pemenuhannya adalah denganmodal asing apabila modal sendiri tidakmencukupi dana untuk kegiatan operasional perusahaan.

Perusahaan dengan ukuran yang lebih besar memiliki akses yang lebih besar untuk mendapat sumber pendanaan dari berbagai sumber, sehingga untuk memperoleh pinjamandari kreditur akan lebih mudah karena perusahaan dengan ukuran besar memiliki probabilitas lebih besar untuk memenangkan persaingan dan bertahan dalam dunia industri.

Ukuran perusahaan menggambarkan besar kecilnya suatu perusahaan yang ditunjukkan dengan total asset, jumlah penjualan, rata-rata tingkat penjualan dan rataratatotal asset, sehingga perusahaan yang lebih kecil akan lebih sulit memperoleh pinjamandaripada perusahaan yang besar, oleh sebab itu besar kecilnya (ukuran) perusahaan akanberpengaruh terhadap struktur modal.

c. Struktur Aktiva

Struktur aktiva merupakan penentuan seberapa besar alokasi untuk masing-masing komponen aktiva, baik dalam aktiva lancar maupun aktiva tetap. Menurut Riyanto (2011) struktur aktiva merupakan perimbangan atau perbandingan antara aktiva lancar dan aktiva tetap.

Perusahaan yang menggunakan hutang jangka pendek adalah perusahaan yang memiliki sebagian besar aktivanya berupa piutang dan persediaan barang yang nilainya sangat tergantung dari tingkat profitabilitas perusahaan, misalnya perusahaan pengecer dan grosir.Kebanyakan perusahaan industri dimana sebagian besar dari modalnya tertanam dalam aktiva tetap, akan mengutamakan pemenuhan kebutuhan modalnya dari modal permanen, yaitu modal sendiri, sedangkan modal asing sifatnya adalah sebagai pelengkap.

d. Pertumbuhan Penjualan

Keberhasilan dari suatu perusahaan dilihat dari kemampuan perusahaan tersebut dalam memperoleh laba.Dari laba yang diperoleh maka perusahaan dapat 
mengembangkan perusahaannya dengan berbagai kegiatan, baik kegiatan lama maupun kegiatan baru, serta meningkatkan jumlah aktiva dan modal perusahaan.Untuk mencapai tujuan tersebut, perusahaan mengandalkan perolehan laba dengan penjualan. Brigham dan Houston (2011) mengatakan bahwa perusahaan dengan penjualan yang relatif stabil dapat secara aman mengambil utang dalam jumlah yang lebih besar dan mengeluarkan beban tetap yang lebih tinggi dibandingkan dengan perusahaan yang penjualannya tidak stabil.

\section{Kerangka Pemikiran.}

Kerangka pemikiran dalam penelitian ini adalah:

\section{Gambar 2.1}

\section{Kerangka Pemikiran}

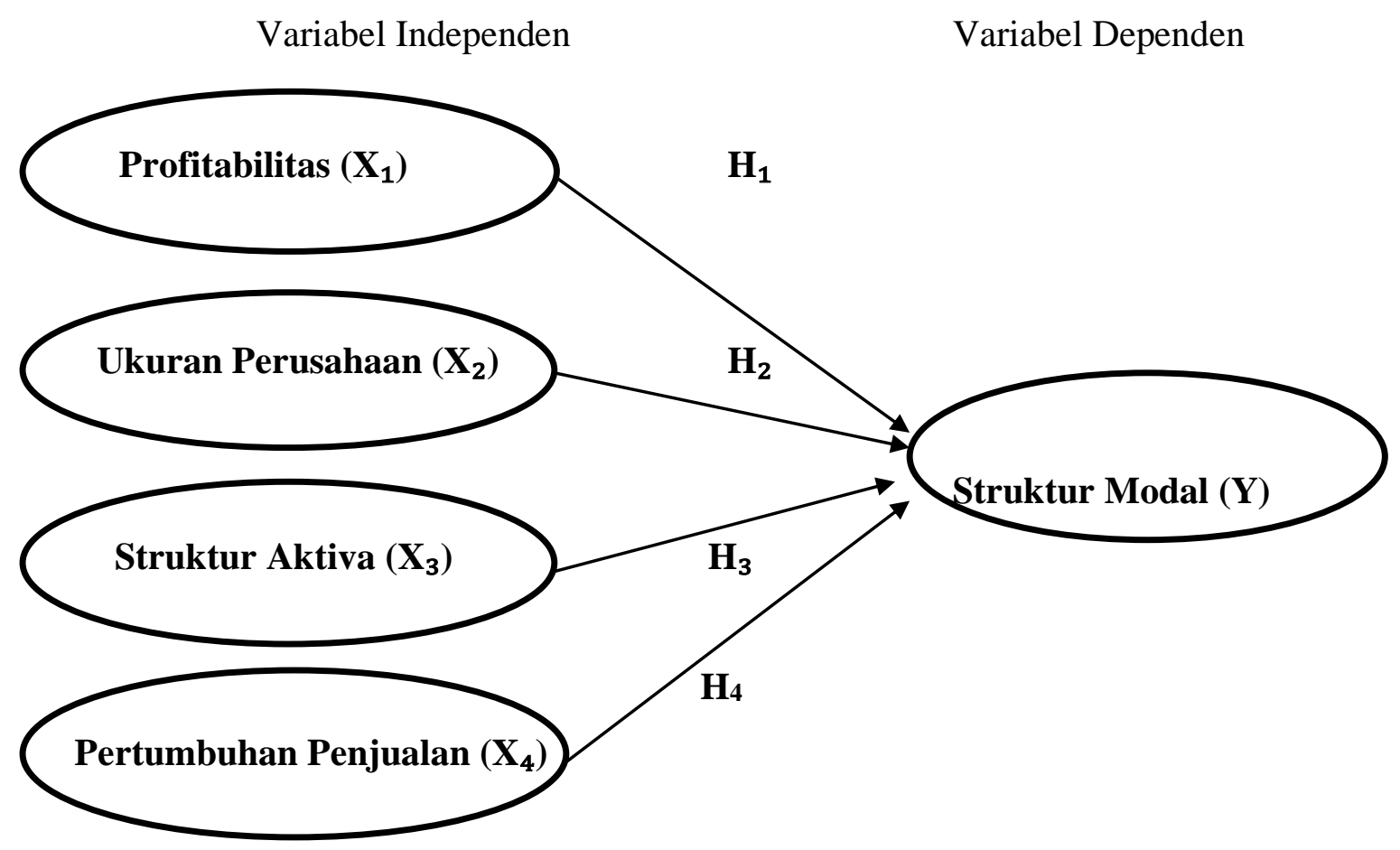

\section{Hipotesis}

Hipotesis dalam penelitian ini adalah:

$\mathrm{H}_{1}$ : Profitabilitas berpengaruh signifikan terhadap Struktur Modal

$\mathrm{H}_{2}$ : Ukuran Perusahaan berpengaruh signifikan terhadap Struktur Modal

$\mathrm{H}_{3}$ : Struktur Aktiva berpengaruh signifikan terhadap Struktur Modal

$\mathrm{H}_{4}$ : Pertumbuhan Penjualan berpengaruh signifikan terhadap Struktur Modal 


\section{METODOLOGI}

\section{Populasi dan Sampel}

Populasi dalam penelitian ini adalah perusahaan manufaktur yang terdaftar di Bursa Efek Indonesia (BEI) tahun 2012-2016sejumlah 149 perusahaan.Sedangkan penentuan sampel menggunakan metode purposive sampling yaitu pengambilan sampel berdasarkan kriteria dansistematika tertentu. Adapun kriteria dalam pengambilan sampel pada penelitian ini adalah sebagai berikut:

a. Perusahaan yang sudah dan masih terdaftar di Bursa Efek Indonesia periode 2012-2016.

b. Perusahaan yang memiliki data keuangan lengkap untuk menghitung variabel-variabel dalam penelitian ini selama periode pengamatan.

c. Perusahaan yang memiliki laba positifselama periode pengamatan.

Berdasarkan kriteria tersebut diperoleh sampel penelitian sebanyak 25 perusahaan.

\section{Variabel Penelitian dan Definisi Operasional}

Variabel dalam penelitian ini ada dua, yaitu variabel bebas dan variabel terikat. Variabel bebas dalam peneltian iniadalah Profitabilitas, Ukuran Perusahaan, Struktur Aktiva dan Pertumbuhan Penjualan. Sedangkan variabel terikat dalam penelitian ini adalah Struktur Modal.

Definisi operasional variabel adalah cara mengukur variabel struktur modal, profitabilitas, ukuran perusahaan, struktur aktiva dan pertumbuhan penjualan.

- Struktur modal, diproksikan dengan Debt to Equity Ratio (DER) yang dapat dihitung dengan rumus:

$$
\mathrm{DER}=\frac{\text { Total Hutang }}{\text { Total Ekuitas }} \times 100 \%
$$

- Profitabilitas, rasio yang digunakan dalam penelitian ini adalah Return On Asset (ROA), yang dapat dihitung dengan menggunakan rumus :

$$
\mathrm{ROA}=\frac{\text { Laba Bersih }}{\text { Total } \text { Asset }} \times 100 \%
$$

- Ukuran perusahaan, menurut Nadeem dan Wang (2011) dalam Lusangaji (2013) ukuran perusahaan dapat dihitung dengan rumus:

$$
\text { Size }=\text { Ln (total aktiva) }
$$

- Struktur Aktiva, menurut Weston dan Copeland (1995) dalam Lusangaji (2013) struktur aktiva dapat dihitung dengan rumus:

$$
\text { Struktur Aktiva }=\frac{\text { Aktiva Tetap }}{\text { Total Aktiva }} \times 100 \%
$$


- Pertumbuhan Penjualan, pengukuran pertumbuhan penjualan dapat dirumuskan sebagai berikut :

$$
\text { Pertumbuhan Penjualan }=\frac{\text { penjualan } t-\text { penjualan }(t-1)}{\text { penjualan }(t-1)}
$$

Metode Pengumpulan Data

Metode pengumpulan data penelitian ini adalah dengan metode dokumentasi, yaitu data yang memuat informasi mengenai suatu obyek atau kejadian masa lalu yang dikumpulkan, dicatat dan disusun dalam arsip (Indriantoro dan Supomo,2002). Sumber data yang digunakan dalam penelitian ini adalahberasal dari IndonesianCapital Market Directory (ICMD) dan laporan keuangan tahunan (annual report) melaluiwww.idx.co.id.

Metode Analisis

Analisis Deskriptif

1. Uji Asumsi Klasik

2. Regresi Linear Berganda

Persamaan dari regresi linear berganda yang digunakan yakni sebagai berikut:

$$
\mathrm{Y}=\mathrm{a}+\mathrm{b}_{1} \mathrm{X}_{1}+\mathrm{b}_{2} \mathrm{X}_{2}+\mathrm{b}_{3} \mathrm{X}_{3}+\mathrm{b}_{4} \mathrm{X}_{4}+\mathrm{e}
$$

Keterangan :

Y

$=$ Struktur Modal

$\mathrm{X}_{1}=$ Profitabilitas

$\mathrm{X}_{2} \quad=$ Ukuran Perusahaan

$\mathrm{X}_{3} \quad=$ Struktur Aktiva

$\mathrm{X}_{4} \quad=$ Pertumbuhan Perusahaan

a $\quad$ konstanta

$b_{1}, b_{2}, b_{3}, b_{4}=$ koefisien regresi

e $\quad=$ error term(kesalahan residual)

3. Goodness Of Fit Model ( Uji Kelayakan Model)

4. Uji Hipotesis (Uji Statistik t)

5. Koefisien Determinasi $\left(\mathrm{R}^{2}\right)$ 


\section{PEMBAHASAN}

\section{Hasil Penelitian}

1. Statistik Deskriptif

Tabel berikut ini menggambarkan statistik deskriptif data penelitian.

Tabel 4.1

Statistik Deskriptif Data-data Penelitian

Periode Tahun 2012-2016

Descriptive Statistics

\begin{tabular}{lccrrr}
\hline & N & Minimum Maximum & Mean & Std. Deviation \\
\hline Struktur Modal & 125 & .22 & 2.73 & .9600 & .49852 \\
Profitabilitas & 125 & .06 & .66 & .2939 & .12354 \\
Ukuran Perusahaan & 125 & .40 & 4.13 & 3.5220 & .71128 \\
Struktur Aktiva & 125 & .20 & .86 & .5504 & .16132 \\
Pertumbuhan Penjualan & 125 & .04 & 2.41 & .3370 & .23816 \\
Valid N (listwise) & 125 & & & & \\
\hline
\end{tabular}

Sumber: Data sekunder yang diolah, 2018

2. Uji Asumsi Klasik

Model yang digunakan dalam regresi memenuhi atau lolos uji asumsi klasik.

3. AnalisisRegresi Linier Berganda

Hasil analisis regresi linier berganda diperoleh persamaan regresi sebagai berikut : $Y=1.170-0.565 X_{1}+0.084 X_{2}+0.876 X_{3}+0.427 X_{4}$

4. Goodness of Fit Model (Uji Kelayakan Model)

Hasil uji Kelayakan Model menunjukkan bahwa model regresi dalam penelitian ini tepat (fit), hal ini ditunjukkan dengan nilai sig $<0,05$. Berikut adalah hasil uji F:

Tabel 4.2

Hasil Uji F

ANOVA $^{b}$

\begin{tabular}{|c|c|c|c|c|c|c|}
\hline \multicolumn{2}{|c|}{ Model } & Sum of Squares & Df & Mean Square & $\mathrm{F}$ & Sig. \\
\hline 1 & Regression & 2.516 & 4 & .629 & 2.667 & $.036^{\circ}$ \\
\hline & Residual & 28.301 & 120 & .236 & & \\
\hline & Total & 30.817 & 124 & & & \\
\hline
\end{tabular}

a. Predictors: (Constant), Pertumbuhan Penjualan, Ukuran Perusahaan, Profitabilitas, Struktur Aktiva

b. Dependent Variable: Struktur Modal

Sumber: Data sekunder yang diolah, 2018 
5. Pengujian Hipotesis

Hasil uji hipotesis (uji t) adalah sebagai berikut:

Tabel 4.3

Hasil Uji Hipotesis (uji t)

Coefficients $^{\mathrm{a}}$

\begin{tabular}{|c|c|c|c|c|c|c|}
\hline \multirow{2}{*}{\multicolumn{2}{|c|}{ Model }} & \multicolumn{2}{|c|}{$\begin{array}{c}\text { Unstandardized } \\
\text { Coefficients } \\
\end{array}$} & \multirow{2}{*}{$\begin{array}{c}\begin{array}{c}\text { Standardized } \\
\text { Coefficients }\end{array} \\
\text { Beta }\end{array}$} & \multirow{2}{*}{$\mathrm{T}$} & \multirow[b]{2}{*}{ Sig. } \\
\hline & & $\mathrm{B}$ & Std. Error & & & \\
\hline \multirow[t]{5}{*}{1} & (Constant) & 1.170 & .245 & & 4.776 & .000 \\
\hline & Profitabilitas (ROA) & -.565 & .373 & -.140 & -1.516 & .132 \\
\hline & $\begin{array}{l}\text { Ukuran Perusahaan } \\
\text { (Size) }\end{array}$ & .084 & .069 & .120 & 1.208 & .229 \\
\hline & Struktur Aktiva (SA) & .876 & .313 & .284 & 2.796 & .006 \\
\hline & $\begin{array}{l}\text { Pertumbuhan } \\
\text { Penjualan (Growth) }\end{array}$ & .427 & .193 & .204 & 2.214 & .029 \\
\hline
\end{tabular}

a. Dependent Variable: Struktur Modal

Sumber : Data sekunder yang diolah, 2018

Dari tabel 4.3 menunjukkan bahwa variabel profitabilitas $\left(\mathrm{X}_{1}\right)$ dan Ukuran perusahaan (size) $\left(\mathrm{X}_{2}\right)$ tidak berpengaruh signifikan terhadap struktur modal, karena nilai signifikansinya $>0,05$. Dengan demikian, hipotesis 1 dan 2 dalam penelitian ini ditolak. Sedangkan variabel Struktur $\operatorname{Aktiva}\left(\mathrm{X}_{3}\right)$ dan pertumbuhan penjualan (Growth) $\left(\mathrm{X}_{4}\right)$ berpengaruh signifikan terhadap Struktur Modal, karena nilai signifikansinya $<0,05$. Dengan demikian hipotesis 3 dan 4 dalam penelitian ini diterima.

6. Koefisien Determinasi

Tabel 4.4

Hasil Uji Koefisien Determinasi

Model Summary ${ }^{\mathrm{b}}$

\begin{tabular}{|c|c|c|c|c|c|}
\hline Model & $\mathrm{R}$ & R Square & $\begin{array}{c}\text { Adjusted R } \\
\text { Square }\end{array}$ & $\begin{array}{l}\text { Std. Error of } \\
\text { the Estimate }\end{array}$ & $\begin{array}{l}\text { Durbin- } \\
\text { Watson }\end{array}$ \\
\hline 1 & $.286^{\mathrm{a}}$ & .182 & .151 & .48564 & 2.195 \\
\hline
\end{tabular}


Dari tabel 4.4diperoleh angka koefisien determinasi (Adjusted $R$ Square) sebesar 0,151. Hal ini berarti bahwa semua variabel independen mampu menjelaskan variabel dependen sebesar15,1\%. Sedangkan sisanya sebesar 84,9\% (100\% - 15,1\%) dijelaskan oleh variabel lain selain variabel dalam penelitian ini.

\section{Pembahasan Penelitian}

1. Pengaruh Profitabilitas (ROA) Terhadap Struktur Modal (DER)

Hasil penelitian menunjukkan bahwa profitabilitastidakberpengaruh signifikan terhadap struktur modal.Penelitian ini sejalan dengan hasil penelitian yang dilakukan oleh Ruswan Nurmadi (2013), yang menyatakan bahwa profitabilitastidak berpengaruh signifikan terhadap struktur modal.Namun tidak sependapat dengan penelitian yang dilakukan olehResti Dara Ayu Aprillia (2015) yang menyatakan bahwa profitabilitas yang diukur dengan ROA berpengaruf negatif dan signifikan terhadap struktur modal (DER).

Pada dasarnyaprofitabilitas adalah kemampuan perusahaan dalam memperoleh laba pada tingkat penjualan, aktiva dan modal.Dilihat dari rata-rata profitabilitas yang dimiliki perusahaan,menunjukkankan bahwa perusahaan masih dapat menghasilkan laba meskipun rendah. Hal ini sesuai dengan pecking order theory bahwa perusahaan lebih mengutamakan pendanaan internal, dengan tingkat profitabilitas yang tinggi, tentu laba yang diperoleh juga besar.Laba ditahan itulah yang dijadikan pendanaan utama untuk mengembangkan usaha dan investasi perusahaan. Maka profitabilitas tinggi atau rendah yang dihasilkan oleh perusahaan tidak dapat mempengaruhi perusahaan untuk menggunakan dana dari luar perusahaan.

2. Pengaruh Ukuran Perusahaan (SIZE) Terhadap Struktur Modal (DER)

Hasil penelitian menunjukkan bahwa ukuran perusahaan (SIZE) tidakberpengaruh signifikan terhadap struktur modal (DER).Penelitian ini sejalan dengan hasil penelitian yang dilakukan oleh Anita Sarly Marentek (2015), yang menyatakan bahwa ukuran perusahaan tidak berpengaruh sigifikan terhadap struktur modal (DER). Sedangkan hasil penelitian yang dilakukan oleh Resti Dara Ayu Aprillia (2015) menyatakan bahwa ukuran perusahaan berpengaruh signifikan terhadap struktur modal (DER).

Hasil ini tidak sesuai dengan landasan teori yang menyatakan bahwa ukuran perusahaan yang lebih besar akan menjamin memiliki akses yang lebih mudah untuk mendapat sumber modalnya. Hasil penelitian ini sesuai dengan pecking order theory 
adalah bahwa perusahaan lebih cenderung menyukai pendanaan yang berasal dari internal dibanding dengan hutang, sehingga ukuran perusahaan tidak memiliki pengaruh terhadap struktur modal.

3. Pengaruh Struktur Aktiva(SA) Terhadap Struktur Modal (DER)

Hasil penelitian menunjukkan bahwa Struktur Aktiva (SA) berpengaruh positif dan signifikan terhadap struktur modal (DER). Penelitian ini sejalan dengan hasil penelitian yang dilakukan oleh Resti Dara Ayu Aprillia (2015) dan Rachma Eka Putri (2014) yang menyatakan bahwa struktur aktiva berpengaruh signifikan terhadap struktur modal. Namun berkebalikan dengan hasil penelitian yang dilakukan oleh Made Yunitri dan Luh Komang (2018) yang menyatakan bahwa struktur aktiva tidak berpengaruh signifikan terhadap struktur modal (DER).

Perusahaan yang berskala besar biasanya memiliki aktiva tetap dalam jumlah besar sehingga perusahaan juga dapat dengan mudah menggunakan banyak utang.Kepemilikan aktiva perusahaan menunjukkan apakah perusahaan memiliki komposisi aktiva yang cocok untuk dijadikan jaminan pengembalian utang.

4. Pengaruh Pertumbuhan Penjualan (Growth) Terhadap Struktur Modal (DER)

Hasil penelitian menunjukkan bahwa Pertumbuhan Penjualan (Growth) berpengaruh positif dan signifikan terhadap struktur modal (DER).Penelitian ini didukung oleh hasil penelitian oleh Rachma Eka Putri (2014) yang menyatakan bahwa pertumbuhan penjualan berpengaruh signifikan terhadap struktur modal.Namun berbanding terbalik dengan penelitian yang dilakukan oleh Eny Maryanti (2016) yang menyebutkan bahwa pertumbuhan penjualan tidak berpengaruh signifikan terhadap struktur modal.

Tingkat pertumbuhan penjualan akan mempengaruhi kemampuan perusahaan dalam mempertahankan keuntungan perusahaan tersebut. Apabila pertumbuhan penjualan perusahaan meningkat maka perusahaan dapat memperoleh keuntungan besar yang dapat digunakan sebagai dana untuk proyek masa mendatang dan juga untuk membayar utang yang dimiliki oleh perusahaan.

\section{KESIMPULAN}

1. Variabel profitabilitas tidak berpengaruh signifikan terhadap struktur modal pada perusahaan manufaktur yang terdaftar di Bursa Efek Indonesia Tahun 2012-2016.

2. Variabel ukuran perusahaan tidak berpengaruh signifikan terhadap struktur modal yang terdaftar di Bursa Efek Indonesia Tahun 2012-2016. 
3. Variabel struktur aktivaberpengaruh signifikan terhadap struktur modal yang terdaftar di Bursa Efek Indonesia Tahun 2012-2016.

4. Variabel pertumbuhan penjualan berpengaruh signifikan terhadap struktur modal yang terdaftar di Bursa Efek Indonesia Tahun 2012-2016.

\section{DAFTAR PUSTAKA}

Andi Kartika, 2009, Faktor-faktor Yang Mempengaruhi Struktur Modal Pada Perusahaan Manufaktur Yang Go Public di BEI, Jurnal Dinamika Keuangan dan Perbankan, Vol. 1 No. 2 Hal. 105-122

Anita S. M., 2015, Analisis Faktor-faktor Yang Mempengaruhi Struktur Modal Perusahaan Manufaktur Yang Tefdaftar di Bursa Efek Indonesia (Pada Perusahaan Food and Beverage Periode 2007 - 2010), Jurnal Berkala Ilmiah Efisiensi, Vol. 15 No. 05

Atmaja, Lukas Setia, 2002, Manajemen Keuangan, Edisi Revisi, Andi, Yogyakarta

Bambang Riyanto, 2010, Dasar-Dasar Pembelanjaan Perusahaan, BPFE, Yogyakarta

Brealey, dkk, 2008, Dasar-dasar Manajemen Keuangan Perusahaan, Jilid 2 Edisi Kelima, Erlangga, Jakarta

Brigham, et all, 1999, Dasar-Dasar Manajemen Keuangan, Penerjemeh Ali Akbar Yulianto, Salemba Empat, Jakarta

Brigham, E.F., dan J. F. Houston, 2011, Dasar-Dasar Manajemen Keuangan, Salemba Empat, Jakarta

Detiana, Tita, 2011, Pengaruh Rasio Keuangan, Pertumbuhan Penjualan dan Dividen Terhadap Harga Saham, Jurnal Bisnis dan Akuntansi, Vol. 13 No. 1 : 57-66

Eny Maryanti, 2016, Analisis Profitabilitas, Pertumbuhan Perusahaan, Pertumbuhan Penjualan dan Struktur Aktiva Terhadap Struktur Modal Pada Perusahaan Sektor Industri Barang Konsumsi Yang Terdaftar di Bursa Efek Indonesia, Riset Akuntansi dan Keuangan Indonesia, 1 (2), Sidoarjo

Erdiana, H. Endah, 2011, Pengaruh Firm Size, Business Risk, Profitability, Assets Growth dan Sales Growth Terhadap Struktur Modal (Studi Kasus Pada Perusahaan Real Estate and Property Yang Terdaftar di BEI Periode 2005-2008), Skripsi, Fakultas Ekonomi, Universitas Diponegoro, Semarang

Ghozali, Imam, 2011, Aplikasi Analisis Multivariate Dengan Program SPSS, Badan Penerbit Universitas Diponegoro, Semarang

Hadianto, Bram, 2010, Pengaruh Struktur Aktiva, Ukuran Perusahaan dan Profitabilitas Terhadap Struktur Modal Emiten Sektor Telekomunikasi Periode 2000-2006, Sebuah Pengujian Hipotesis Pecking Order, Jurnal Manajemen : 14-39 
Husnan, Suad, 2011, Manajemen Keuangan Teori dan Penerapan (Keputusan Jangka Pendek), BPFE, Yogyakarta

Indriantoro dan Supomo, 2002, Metodologi Penelitian Bisnis, BPFE UGM, Yogyakarta

Sartono, R. Agus, 2009, Manajemen Keuangan, Edisi 3, BPFE UGM, Yogyakarta

Sartono, R. Agus dan Ragil Sriharto, 1999, Faktor-faktor Yang Mempengaruhi Struktur Modal Perusahaan Manufaktur di Indonesia, Sinergi, Vol. 2 No. 2 P. 175-188

Sugiyono, 2009, Metode Penelitian Bisnis, Alfabeta, Bandung

Weston \& Brigham, 1991, Dasar-Dasar Manajemen Keuangan, Edisi Ketujuh, Jilid Pertama, Erlangga, Jakarta 